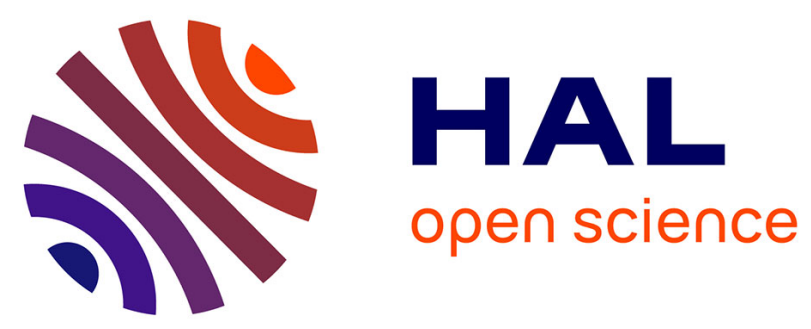

\title{
A model for the CdS solar cell
}

E.R. Hill, B.G. Keramidas

\section{- To cite this version:}

E.R. Hill, B.G. Keramidas. A model for the CdS solar cell. Revue de Physique Appliquée, 1966, 1 (3), pp.189-193. 10.1051/rphysap:0196600103018900 . jpa-00242713

\section{HAL Id: jpa-00242713 https://hal.science/jpa-00242713}

Submitted on 1 Jan 1966

HAL is a multi-disciplinary open access archive for the deposit and dissemination of scientific research documents, whether they are published or not. The documents may come from teaching and research institutions in France or abroad, or from public or private research centers.
L'archive ouverte pluridisciplinaire HAL, est destinée au dépôt et à la diffusion de documents scientifiques de niveau recherche, publiés ou non, émanant des établissements d'enseignement et de recherche français ou étrangers, des laboratoires publics ou privés. 


\title{
A MODEL FOR THE CdS SOLAR CELL $\left({ }^{1}\right)$
}

\author{
By E. R. HILL and B. G. KERAMIDAS, \\ Harshaw Chemical Company, Cleveland, Ohio.
}

\begin{abstract}
Résumé. - La cellule solaire au CdS est un dispositif photovoltaïque constitué d'un film mince évaporé de CdS et d'une couche de sulfure de cuivre formé par voie chimique. Les techniques actuelles de préparation donnent des cellules solaires de rendement de conversion 5 à $6 \%$ pour des surfaces atteignant $50 \mathrm{~cm}^{2}$. La jonction photovoltaïque est formée en immergeant le film mince de $\mathrm{CdS}$ dans une solution aqueuse acidifiée de $\mathrm{Cu}_{2} \mathrm{Cl}_{2}$.

On présente un modèle qui explique les réactions chimiques responsables de la formation de la couche de sulfure de cuivre, de type $p$, sur le CdS de type $n$, et par suite d'une jonction $p-n$ Ce modèle explique en outre les propriétés physiques, électriques et photoélectriques du dispositif et son mode de fonctionnement.
\end{abstract}

Abstract. - The CdS solar cell is a photovoltaic device made from a thin evaporated film of CdS and a chemically formed layer of copper sulfide. Present techniques of fabrication give solar cells with conversion efficiencies of 5 to $6 \%$ on areas as large as $50 \mathrm{~cm}^{2}$.

The photovoltaic junction is formed by immersing the CdS thin film into an acidified aqueous solution of $\mathrm{Cu}_{2} \mathrm{Cl}_{2}$.

A model is presented which explains the chemical reactions responsible for the formation of the $p$-type copper sulfide layer into the $n$-type CdS material and the $p-n$ junction consequently formed.

The model further explains the physical, electrical, and photoelectric properties of the device and its mode of operation.

The photovoltaic effect in CdS was first discovered by D. C. Reynolds in 1954 [1]. He plated copper onto one face of a CdS crystal, heated it, and found a sizable photovoltaic effect, to exist. Later, Cusano [2] found a similar effect in CdTe and concluded that a chemical reaction of $\mathrm{CdS}$ and $\mathrm{CdTe}$ with Copper in solution produced $\mathrm{Cu}_{2} \mathrm{~S}$ and $\mathrm{Cu}_{2} \mathrm{Te}$ layers on the parent materials. These $\mathrm{Cu}_{2} \mathrm{~S}$ and $\mathrm{Cu}_{2} \mathrm{Te}$ layers are always $p$-type and highly conductive. Thus, when formed on an $n$-type sem1conductor such as CdS, a rectifying junction results. Different methods of forming the layers and junctions have been used with varving degrees of success. For CdS, the most widely used process is a chemical dip and this paper is concerned with an analysis of some of the properties of the resulting cell.

The base material for the solar cell is a single crystal or a thin film of CdS which has been evaporated onto a metal substrate. The film is dipped into a solution mad with acidified hot water and $\mathrm{Cu}_{2} \mathrm{Cl}_{2}$. The chemical reaction which occurs is described by the following equation since the ions of copper and cadmium are the active species :

$$
\begin{gathered}
\mathrm{Cu}_{2}^{+2}+\mathrm{CdS}=\mathrm{Cu}_{2} \mathrm{~S}+\mathrm{Cd}^{+2} \\
\Delta F^{\mathrm{c}}\left(298^{\circ} \mathrm{K}\right)=-12 \frac{\mathrm{kcal}}{\text { mole }} .
\end{gathered}
$$

(1) This work was supported by a grant from the Harshaw Chemical Company, and by contracts from NASA, Lewis Laboratory, and Wright-Patterson Air Force Base.
Thermodynamically, the reaction proceeds to the right by virtue of the lower free energy of the reaction products on the right hand side. Kinetically, the reaction is aided by the high water solubility of $\mathrm{CdCl}_{2}$. At equlibrium, the concentrations of the components are related by the following equation :

$$
\operatorname{Ln} \frac{\left[\mathrm{Cd}^{+2}\right]\left[\mathrm{Cu}_{2} \mathrm{~S}\right]}{\left[\mathrm{Cu}_{2}^{+2}\right][\mathrm{Cd} \mathrm{S}]}=--\frac{\Delta F \mathrm{o}}{R T}
$$

bracket denotes concentration of component.

$$
\begin{aligned}
& \Delta F^{\mathrm{o}}=\text { free energy of the reaction. } \\
& R=\text { universal gas constant. } \\
& T=\text { absolute temperature. }
\end{aligned}
$$

For the temperature range of interest, $\Delta F^{\circ}$ is essentially constant and the right hand term is a function of temperature only.

$\mathrm{Cu}_{2} \mathrm{~S}$ as made in this manner is a $p$-type semiconductor with a band gap near $1 \mathrm{eV}$ and a hole concentration of anout $10^{22}$ per $\mathrm{cm}^{2}$. CdS is $n$-type with a band gap of $2.4 \mathrm{eV}$ and an electron concentration of about $10^{22}$ per $\mathrm{cm}^{2}$. Consequently, if these materials are joined properly, a rectifying junction will result. The diode formed by this chemical process has a high saturation current on the order of microamperes per $\mathrm{cm}^{2}$ and is in general rather leaky. When illuminated with sunlight, it generates power. A schematic representation of the cell structure is shown in Figure 1. A typical spectral response of short circuit current is shown 


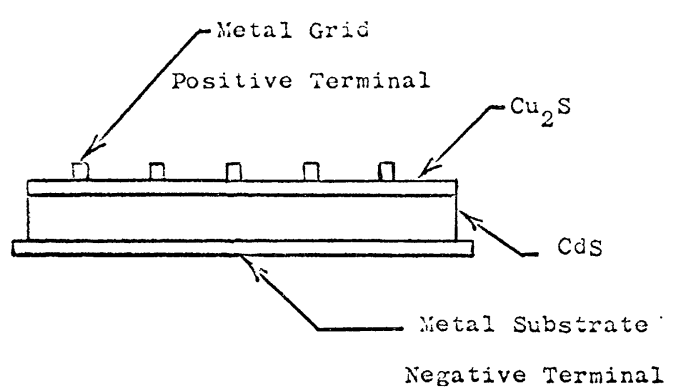

FIG. 1. - Physical schematic cross section of CdS solar cell.

in Figure 2. The only unusual aspect of the response is the threshold at about $1 \mathrm{eV}$. Photons are absorbed near a rectifying junction in $1 \mathrm{eV}$ bandgap material and the resulting hole-electron pairs are collected. No change in the response is seen at $2.4 \mathrm{eV}$, so that CdS is not playing an active part in this type of cell.

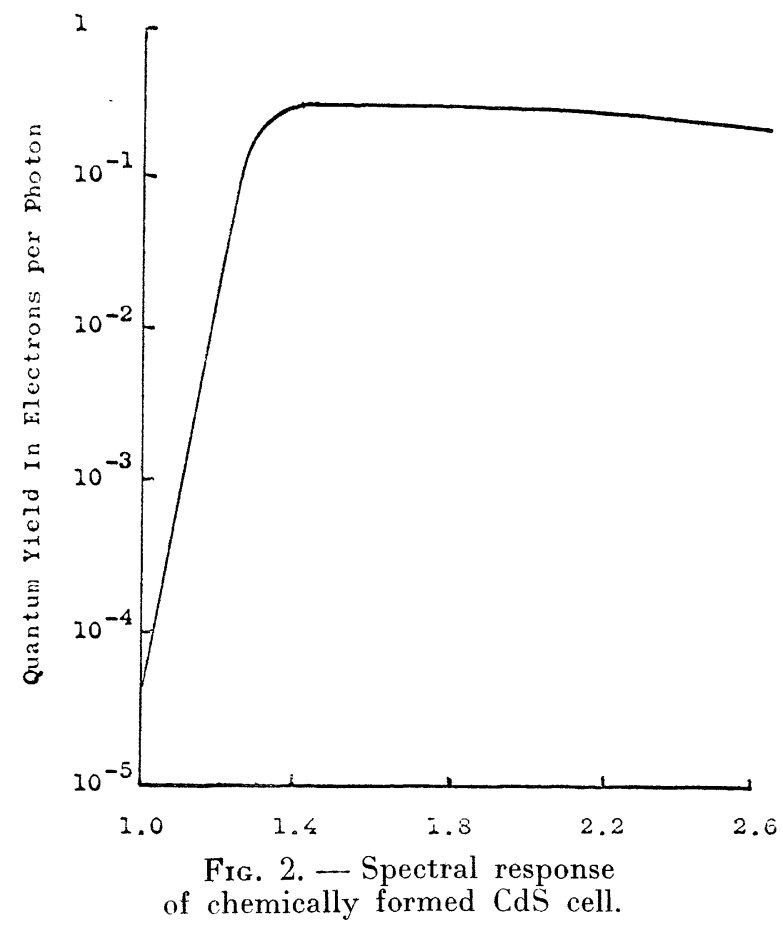

To understand the more detailed nature of the cell, it is necessary to examine the process on a microscopic level. The chemical reaction is a double displacement type which requires that each time two $\mathrm{Cu}^{+}$ions enter the $\mathrm{CdS}$ film, one $\mathrm{Cd}^{2+}$ ion must leave. If the CdS is highly ordered as in the case of a single crystalline face, only a few monolayers of $\mathrm{Cu}_{2} \mathrm{~S}$ are formed. This is to be expected since few sites of high chemical activity such as dislocations and grain boundaries are present. Also the reaction takes place at a temperature around
$100{ }^{\circ} \mathrm{C}$, and the diffusion coefficients of the components in CdS will be low. However, if the CdS is highly disordered as in the case of a polycrystalline film or a lapped single crystal, regions of high chemical activity are plentiful and diffusion is enhanced by the presence of grain boundaries and dislocations. In fact, chemical action penetrates to depths of several microns in evaporated films.

In order for the chemical reaction to occur past the solid surface, diffusion of the reactants must. take place which implies concentration gradients. Figure 3 shows a schematic picture of the CdS cell cross-section representing the material distribution in the cell at any time after immersion in the solution. As can be seen, a gradient of $\mathrm{Cu}^{+}$ions and $\mathrm{Cu}_{2} \mathrm{~S}$ extends into the $\mathrm{CdS}$ and a gradient of CdS and $\mathrm{Cd}++$ ions extends out to the surface. These gradients must exist for the reaction to proceed at all, and consequently must exist in the cell when it is removed from the solution. When it reaches thermal equilibrium after the chemical treatment, it will still be in a state of chemical non-equilibrium, since the concentration gradients are still present. This can be called a state of quasi-chemical equilibrium : i.e., over a small region, equation (2)

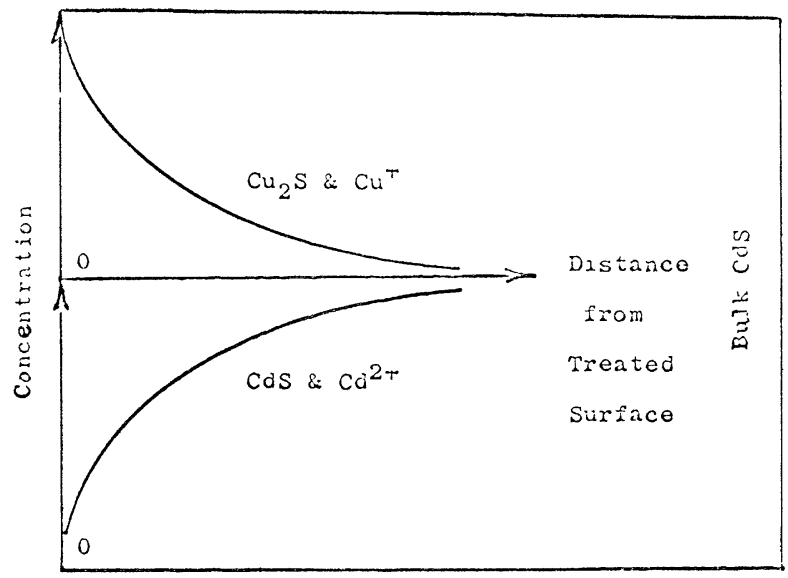

FIg. 3. - Schematic cross section of CdS cell junction.

which governs the component concentrations will be only slightly perturbed.

Ultimately, in deference to the second law of thermodynamics, a state of equilibrium will be reached where all four reaction components are uniformiy distributed throughout the solid and are in equilibrium with their vapor state. The rate at which this condition is approached is determined by the mobilities and concentration gradients of the species and the temperature. At room temperature, this occurs very slowly, but over a period of weeks, it can be detected by changes in the cell's I-V curve.

When the cell is heated, however, this tendency is accelerated and five minutes at $250^{\circ} \mathrm{C}$. produces a 
marked change. It is unlikely that the $\mathrm{Cu}_{2} \mathrm{~S}$ and C.dS molecules will be particularly mobile, but $\mathrm{Cd}++$ and $\mathrm{Cu}^{+}$ions can move. They will slide down their gradients, increasing the $\mathrm{Cu}^{+}$concentration inside and increasing the $\mathrm{Cd}++$ concentration near the surface. Equation (2) implies an increasing CdS concentration near the surface and increasing $\mathrm{Cu}_{2} \mathrm{~S}$ concentration deeper in the cell. Figure 4 shows the spectral response of the cell in this condition. The most significant feature is the step at $2.4 \mathrm{eV}$ which says that carriers are produced in CdS within a diffusion length of the electrical junction. This is due to CdS mixed in with the $\mathrm{Cu}_{2} \mathrm{~S}$ near the surface of the cell. The I-V curve shown in Figure 5 indicates a reasonably good diode and a true generated short circuit current.

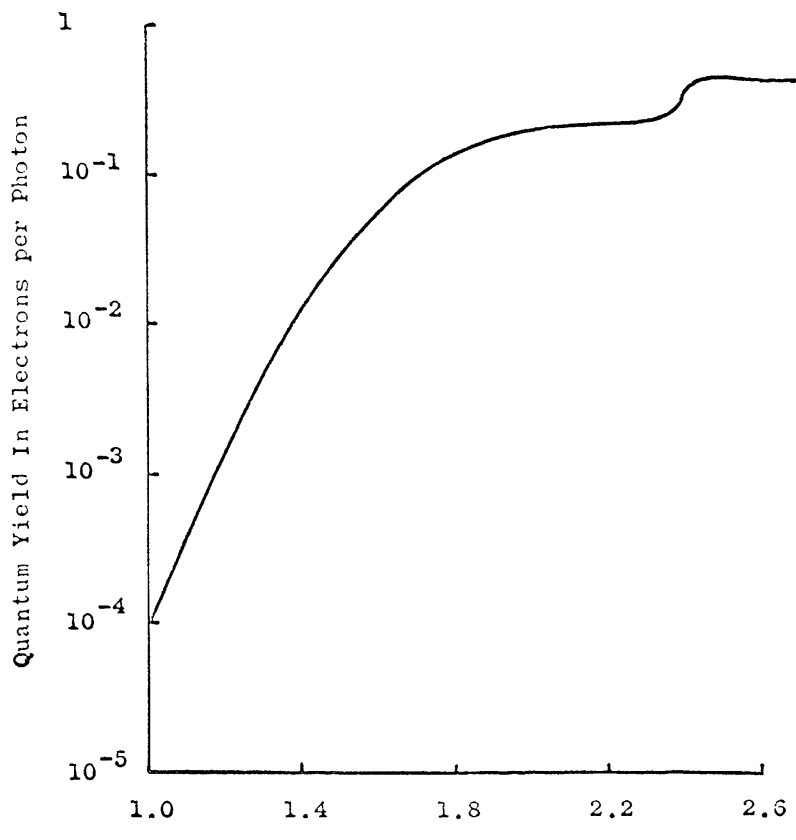

Fig. 4. - Spectral response

of $\mathrm{CdS}$ cell heated for 5 minutes at $250^{\circ} \mathrm{C}$.

The cell is most useful for solar power conversion when in this condition. It is in many respects similar to the silicon cell, and has many of its properties.

A $p$-n homojunction such as the silicon solar cell changes character with temperature. The bandgap decreases with increasing temperature, causing the threshold for spectral response to shift toward the red end of the spectrum. Thermally generated minority carriers also increase, causing the saturation current to increase and the open circuit voltage to decrease. The short circuit current of quantum yield is independent of temperature for photon energies greater than the bandgap.

The open circuit voltage and spectral response threshold vary in the same manner in the CdS cell.

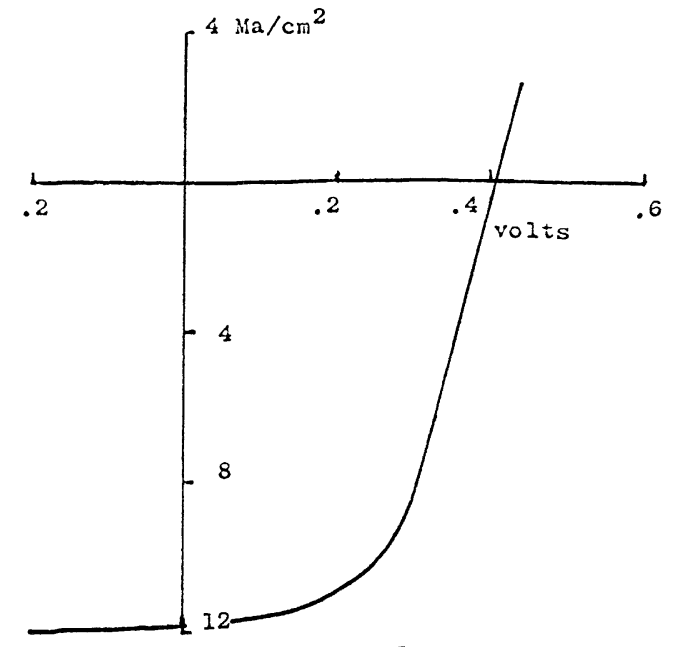

Fig. 5. - I-V curve

of CdS cell heated 5 minutes at $250^{\circ} \mathrm{C}$.

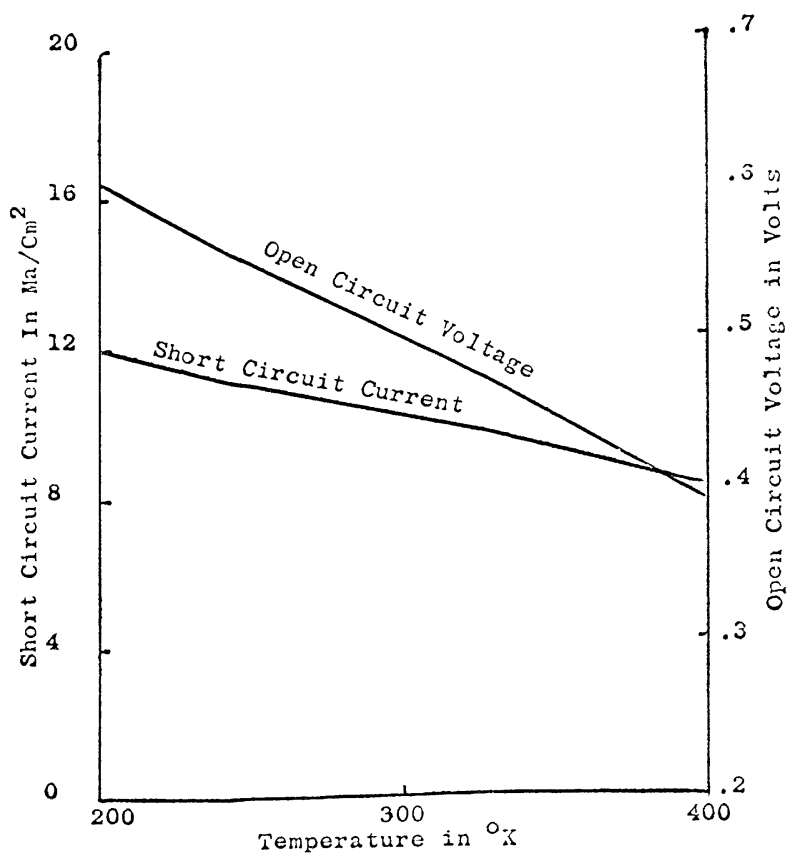

Fig. 6. - Temperature dependence of open circuit voltage and short circuit current for $\mathrm{CdS}$ solar cell.

In addition, the short circuit current is also temperature dependent. Figure 6 shows the change in solar generated short circuit current and open circuit voltage with temperature. Figure 7 shows the change in spectral response over the same temperature range. The change in open circuit voltage and the response threshold are as expected. The change in short circuit current is seen to correspond to a decrease in quantum yield in the range from about $1.7 \mathrm{eV}$ to $2.4 \mathrm{eV}$. This can be explained by examining equation (2) again. As temperature increases, the right hand term becomes a 


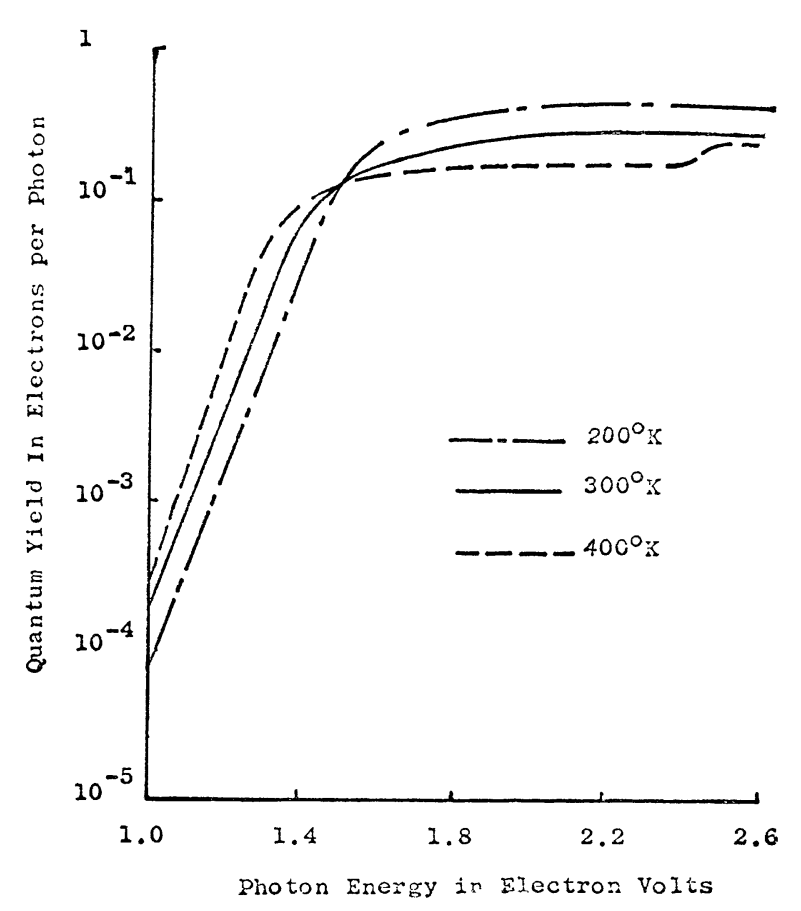

Fig. 7. - Temperature variation of CdS solar cell spectral response.

smaller negative number or increases. Thus, the ratio of concentration on the left must increase with $\mathrm{CdS}$ increasing and $\mathrm{Cu}_{2} \mathrm{~S}$ decreasing. Since the response from 1.7 to $2.4 \mathrm{eV}$ comes from absorption in $\mathrm{Cu}_{2} \mathrm{~S}$, it will also decrease. The increase in response at $2.4 \mathrm{eV}$ is seen to correspond to an increase in $\mathrm{CdS}$ concentration near the surface.

If this cell is further heated for one hour at $350^{\circ} \mathrm{C}$, the gradients of concentration will become even flatter. The electrical junction should correspond to the region of chemical iransition and will then become broader. It vill also move further into the bulk CdS. Figure 8 shows the spectral response of a cell subjected to such a treatment. Again, the most striking feature is the behavior at $2.4 \mathrm{eV}$ where there is now almost a complete loss of response. Evidently a great deal of CdS has formed near the surface and the junction has been moved deep inside the cell.

The I-V curve, shown in Figure 9 indicates a relatively low collected short circuit current, and even begins to look like two junctions may be present. Thus, photons with energy above $2.4 \mathrm{eV}$ are absorbed near the surface, resulting in a low quantum yield. This low vield can be due simply to having the junction far inside the cell or to the presence of a second junction in the opposite direction.

Further heating causes additional change and after 15 minutes at $600{ }^{\circ} \mathrm{C}$ the cell is useless as a power converter but has developed a very inte-

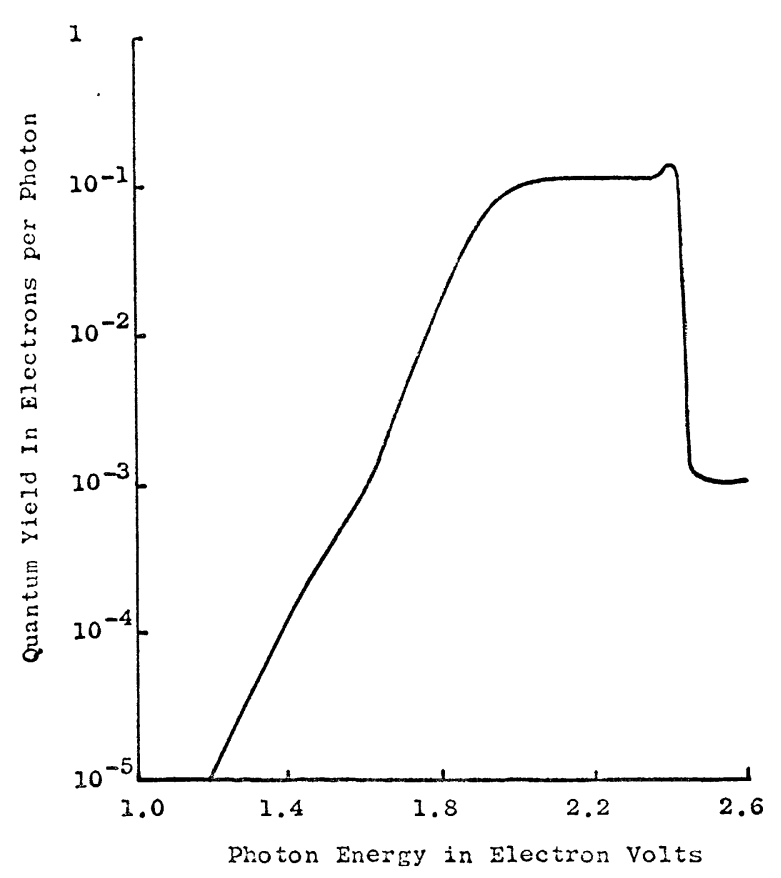

FIG. 8. - Spectral response of CdS cell heated 1 hour at $350^{\circ} \mathrm{C}$.

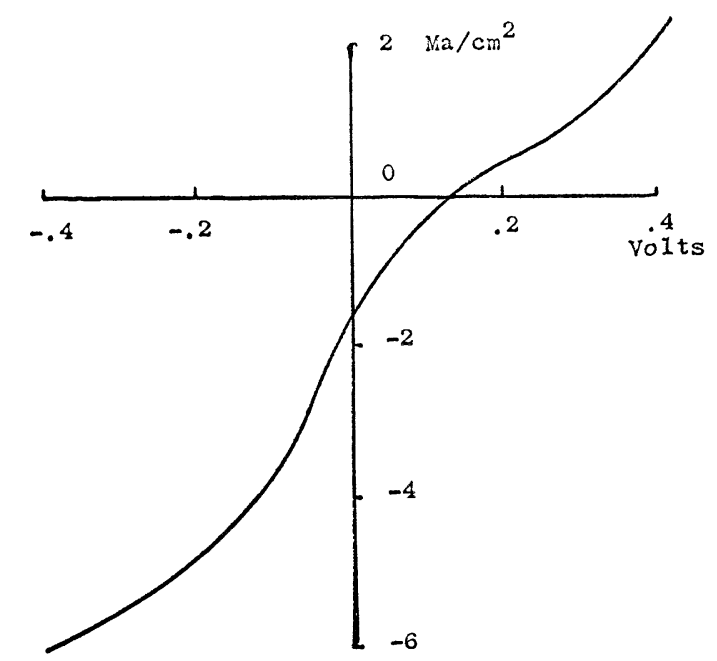

Fig. 9. - I-V curve for $\mathrm{CdS}$ cell heated 1 hour at $350^{\circ} \mathrm{C}$.

resting behavior. Figure 10 shows the spectral response of the generated current which can be seen to reverse direction with color of illumination. For red and infrared light, the current is of the sign produced by the cell initially. That is, the treated surface is positive and the bulk CdS negative. For green and blue light, the polarity reverses. For tungsten illumination, the net current is generally reversed from that of the normal cell. Red light is weakly absorbed and generates carriers deep in the cell near the normal $\mathrm{Cu}_{2} \mathrm{~S}$-CdS junction. These carriers are separated and produce normally directed 


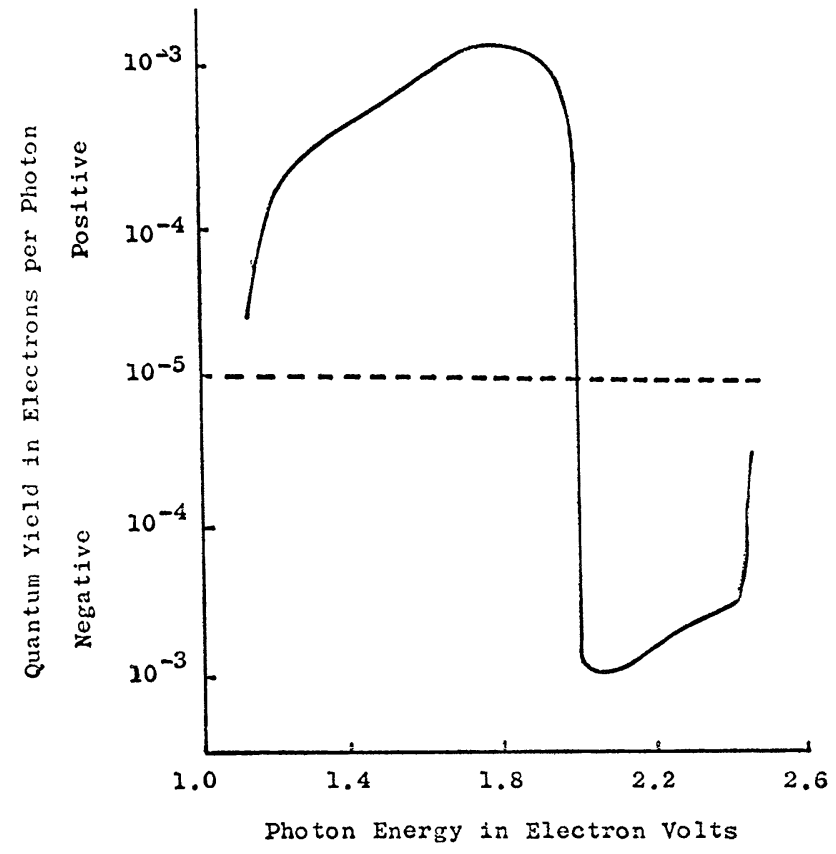

FIG. 10. - Spectral response of $\mathrm{CdS}$ cell heated 15 minutes at $600^{\circ} \mathrm{C}$.

current. Green light is more strongly absorbed near the surface and produces oppositely directed current. This can be due to either non-uniform absorption as in the Dember effect, or due to the presence of a second junction with the opposite sense. Additional heating merely results in material homogenization and loss due to evaporation.

This has been a limited discussion of the CdS cell in that only a few salient points have been examined and many microscopic details have been glossed over. For instance, $\mathrm{Cu}_{2} \mathrm{~S}$ and $\mathrm{CdS}$ are only weakly soluble in each other and undoubtedly the chemical transition region is composed of aggregates of clusters. On the atomic scale, this is a discontinuous structure, but on the scale of the Debye length for carriers, this is small. Likewise the transport equation for the heterojunction has been neglected, and the assumption made that a junction exists in a chemical transition region.

The important point is that the device is the result of a double displacement chemical reaction which stops before equilibrium is reached. Thus, concentration gradients of the reactants exist in the region of chemical change. Since the initial reaction occurs near room temperature, even moderate heating can be expected to alter the distribution of the reactants. From the chemical equation and a knowledge of the gradients, the direction of material redistribution can be predicted. The behavior of the cell after various heating cycles can be correlated with the qualitative picture of the material distribution and their electrical and optical pro. perties.

\section{REFERENCES}

1) Reynolds (D. C.), Leies (G.) and Antes (L. L.), Photovoltaic Effect in cadmium sulfide. Phys. Rev., 15 Oct. 1954, 96, 533-534.
[2] Cusano (D. A.), CdTe solar cells and photovoltalt leterojunctions in II-VI compounds. Solid. Statc Electronics, 1963, 6, 217-232. 